\title{
The Change of Taurine Transport in Variable Stress States through the Inner Blood-Retinal Barrier using In Vitro Model
}

\author{
Young-Sook KANG*, Na-Young LeE, and Yeon-Yee Chung \\ College of Pharmacy and Research Institute of Pharmaceutical Sciences, Sookmyung Women's University, Seoul 140-742, Korea
}

(Received February 9, 2009; Accepted March 22, 2009 )

\begin{abstract}
Taurine is the most abundant free amino acid in the retina and transported into retina via taurine transporter (TauT) at the inner blood-retinal barrier (iBRB). In the present study, we investigated whether the taurine transport at the $\mathrm{BRRB}$ is regulated by oxidative stress or disease-like state in a conditionally immortalized rat retinal capillary endothelial cell line (TR-iBRB) used as an in vitro model of iBRB. First, $\left[{ }^{3} \mathrm{H}\right]$ taurine uptake and efflux by TR-iBRB were regulated in the presence of extracellular $\mathrm{Ca}^{2+}$. $\left.{ }^{3} \mathrm{H}\right] \mathrm{Taurine}$ uptake was inhibited and efflux was enhanced under $\mathrm{Ca}^{2+}$ free condition in the cells. In addition, oxidative stress inducing agents such as tumor necrosis factor- $\alpha$ (TNF- $\alpha$ ), lipopolysaccharide (LPS), diethyl maleate (DEM) and glutamate increased $\left[{ }^{3} \mathrm{H}\right]$ taurine uptake and decreased $\left[{ }^{3} \mathrm{H}\right]$ taurine efflux in TR-iBRB cells. Whereas, 3-morpholinosydnonimine (SIN-1), which is known to NO donor decreased $\left[{ }^{3} \mathrm{H}\right]$ taurine uptake. Lastly, TR-iBRB cells exposed to high glucose $(25 \mathrm{mM})$ medium and the $\left[{ }^{3} \mathrm{H}\right]$ taurine uptake was reduced about $20 \%$ at the condition. Also, $\left[{ }^{3} \mathrm{H}\right]$ taurine uptake was decreased by cytochalasin $\mathrm{B}$, which is known to glucose transport inhibitor. In conclusion, taurine transport in TR-iBRB cells is regulated diversely at extracellular $\mathrm{Ca}^{2+}$, oxidative stress and hyperglycemic condition. It suggested that taurine would play a role as a retinal protector in diverse disease states.
\end{abstract}

Keywords: Taurine transport, Inner blood-retinal barrier, Conditionally immortalized rat retinal capillary endothelial cells, Oxidative stress, Hyperglycemic condition, Extracellular calcium

\section{INTRODUCTION}

Taurine, a $\beta$-aminosulfonic acid, possesses variable functions during development and regeneration of the retina. The retina synthesize and uptake taurine, which is the most abundant free amino acid in the retina and occupies more than $50 \%$ of the free amino acid content in the retina (Lima, 1999). Deficiency of taurine alters the structure and the function of the retina (Hayes et al., 1975; Obrosova et al., 2001). Although abnormal electroretinograms and visual disturbance were found in patient undergoing long-term parental nutrition lacking taurine, these abnormalities were returned to normal by adding taurine intravenously (Vinton et al., 1990).

The retina, a highly differentiated tissue involved in the function of sight, has a blood-retinal barrier (BRB) to prevent any non-specific transport of substrates from the cir-

${ }^{*}$ Corresponding author

Tel: +82-2-710-9562 Fax: +82-2-2077-7975

E-mail : yskang@sm.ac.kr culating blood (Stewart and Tuor, 1994). The BRB is composed of retinal capillary endothelial cells (inner BRB) and retinal pigment epithelial cells (RPE, outer BRB) (CunhaVaz, 1976; Stewart and Tuor, 1994). The retinal uptake index method demonstrated $\left[{ }^{3} \mathrm{H}\right]$ taurine uptake from the circulating blood to the retinal across the BRB (Tornquist and Alm, 1986) and its inhibition by excess amount of taurine and $\beta$-alanine. The transport of $\beta$-amino acid such as taurine and $\beta$-alanine is known to be mediated $\mathrm{Na}^{+}$and $\mathrm{Cl}^{-}$dependent taurine transporter (Smith et al., 1992). Taurine transporter (TauT) knockout mice were reported to exhibit a loss of vision due to severe retinal degenerations (Heller-Stilb et al., 2002). This report suggested that TauT is critical for normal retinal development and function.

In the retina, diverse neuroprotective functions have been ascribed to taurine. Cells achieve osmotic equilibrium by accumulating or losing inorganic ions and organic molecules, and retinal taurine is known to one of an ideal osmolyte (Pasantes-Morales et al., 1972). Taurine also plays as an antioxidant in the retina and taurine deficiency 
can result in retinal degeneration (Lima, 1999). Accordingly, transport activity of taurine may be also changed at the inner BRB (iBRB) under the pathophysiological conditions, and this change could intensely affect the neuroprotective effect of taurine by influencing taurine concentration in the retina. However, the regulation of taurine transport at the iBRB remains uncertain at the present time.

TR-iBRB cell lines, conditionally immortalized rat retinal capillary endothelial cell lines, have been recently established by transfecting the retrovirus vector-encoded temperature-sensitive (ts) simian virus (SV) 40 large T-antigen (Hosoya et al., 2001). This cell lines are good in vitro model for drug transport to the retina and as a screening tool for drugs which might be capable of delivery to the retina (Terasaki and Hosoya, 2001). RT-PCR and immunoblot analysis showed that TauT is expressed in rat retina and TR-iBRB cells. And, immunohistochemical analysis revealed that TauT was expressed in retinal vessel in the ganglion cell layer (Hosoya et al., 2001).

The purpose of this study is to clarify the regulation of taurine transport activity by extracellular $\mathrm{Ca}^{2+}$ concentration, oxidative stresses and hyperglycemia using TRiBRB cell lines as an in vitro model of iBRB.

\section{MATERIALS AND METHODS}

\section{Materials}

$\left[{ }^{3} \mathrm{H}\right]$ Taurine $(20 \mathrm{Ci} / \mathrm{mmol})$ was thankfully provided by Dong-A Pharmaceutical (Seoul, Korea). Taurine, tumor necrosis factor- $\alpha$ (TNF- $\alpha$ ), lipopolysaccharide (LPS), glutamate, 3-morpholinosydnonimine (SIN-1), verapamil, nifedifine, nickel chloride $\left(\mathrm{NiCl}_{2}\right)$ and cytochalasin $\mathrm{B}(\mathrm{CB})$ were purchased from Sigma Chemical (St. Louis, MO, USA). Diethyl maleate (DEM) was purchased from Aldrich Chemical (St. Louis, MO, USA). All other chemicals were commercial products of reagent grade.

\section{Cell culture}

The TR-iBRB cells were grown routinely in rat tail collagen type 1-coated tissue culture dishes (Iwaki, Tokyo, Japan) at $33^{\circ} \mathrm{C}$ and cultured in a humidified atmosphere of $5 \% \mathrm{CO}_{2} /$ air. The cells were cultured in Dulbecco's modified Eagle's medium (DMEM; Invitrogen, Grand Island, NY, USA) supplemented with $10 \%$ fetal bovine serum (FBS; Invitrogen, Grand Island, NY, USA), $15 \mu \mathrm{g} / \mathrm{L}$ endothelial cell growth factor (Roche, Mannheim, Germany), $100 \mathrm{U} / \mathrm{ml}$ penicillin and $100 \mu \mathrm{g} / \mathrm{ml}$ streptomycin (Invitrogen, Grand Island, NY, USA).

\section{$\left[{ }^{3} \mathrm{H}\right]$ Taurine uptake study in the TR-iBRB cells}

TR-iBRB cells were cultured at $33^{\circ} \mathrm{C}$ on rat tail collagen type 1-coated 24-well plates (Iwaki, Tokyo, Japan) for 2 days and washed with $1 \mathrm{ml}$ extracellular fluid (ECF) buffer consisting of $122 \mathrm{mM} \mathrm{NaCl}, 25 \mathrm{mM} \mathrm{NaHCO}_{3}, 3 \mathrm{mM} \mathrm{KCl}$, $1.4 \mathrm{mM} \mathrm{CaCl}_{2}, 1.2 \mathrm{mM} \mathrm{MgSO}_{4}, 0.4 \mathrm{mM} \mathrm{K}_{2} \mathrm{HPO}_{4}, 10 \mathrm{mM}$ D-glucose and $10 \mathrm{mM}$ Hepes $\left(\mathrm{pH} \mathrm{7.4)}\right.$ at $37^{\circ} \mathrm{C}$. Uptake was initiated by addition of $200 \mu \mathrm{l} \mathrm{ECF}$ buffer containing $\left[{ }^{3} \mathrm{H}\right]$ taurine at $37^{\circ} \mathrm{C}$. After appropriate time periods, uptake was terminated by removing the solution and washed with $1 \mathrm{ml}$ ice-cold ECF buffer. To investigate the change of taurine uptake under several stress conditions, the TR- iBRB cells were pretreated with $20 \mathrm{ng} / \mathrm{ml}$ TNF- $\alpha, 10 \mathrm{ng} / \mathrm{ml}$ LPS, $100 \mu \mathrm{M}$ DEM, $100 \mu \mathrm{M}$ glutamate, $1 \mathrm{mM}$ SIN-1, $25 \mathrm{mM}$ glucose, or $1 \mu \mathrm{M}$ CB for $3,6,9,12$ and $24 \mathrm{~h}$ and the uptake study was performed as described above. Then, the cells were dissolved in $1 \mathrm{~N} \mathrm{NaOH}$ overnight at room temperature. An aliquot ( $50 \mu \mathrm{l})$ was taken for protein assay using a DC protein assay kit (Bio-Rad, Hercules, CA, USA) with bovine serum albumin as a standard. The remaining solution $(500 \mu \mathrm{l})$ was mixed with $4.5 \mathrm{ml}$ of scintillation cocktail (Hionic-fluor, Packard, Meriden, CT, USA) for the measurement of radioactivity using a liquid scintillation counter (LS6500, Beckman Instruments Inc. Fullerton, CA, USA).

\section{Measurements of $\left[{ }^{3} \mathrm{H}\right]$ taurine efflux in the TR-iBRB cells}

TR-iBRB cells were cultured at $33^{\circ} \mathrm{C}$ on rat tail collagen type 1-coated 24-well plates and washed with $1 \mathrm{ml} \mathrm{ECF}$ at $37^{\circ} \mathrm{C}$. The cells were first incubated with $200 \mu \mathrm{lECF}$ buffer containing $\left[{ }^{3} \mathrm{H}\right]$ taurine at $37^{\circ} \mathrm{C}$ for 60 min to uptake $\left[^{3} \mathrm{H}\right]$ taurine. After incubation, the solution was removed and the cells were washed with $1 \mathrm{ml}$ ice-cold ECF buffer. Then, the media were replaced with the $1 \mathrm{ml}$ ECF buffer and the cells were further incubated at $37^{\circ} \mathrm{C}$ for various time period to allow efflux of $\left[{ }^{3} \mathrm{H}\right]$ taurine. The cells were then solubilized in $1 \mathrm{~N} \mathrm{NaOH}$ overnight at room temperature. An aliquot was taken for protein assay and the measurements of the amount of $\left[{ }^{3} \mathrm{H}\right]$ taurine remaining in the cells.

\section{Data analysis}

All data represent mean \pm S.E.M. Statistical analyses were carried out by one-way ANOVA with Dunnett's posthoc test and $p<0.05$ was considered statistically significant.

\section{RESULTS}

\section{Effects of ion and calcium channel blockers on $\left[{ }^{3} \mathrm{H}\right]$ taurine uptake and efflux in TR-iBRB cells}

The effect of extracellular $\mathrm{Ca}^{2+}$ on uptake and efflux of $\left[{ }^{3} \mathrm{H}\right]$ taurine were examined under $\mathrm{Na}^{+}, \mathrm{Cl}^{-}$and $\mathrm{Ca}^{2+}$ free 
or $\mathrm{Ca}^{2+}$ excess condition in TR-iBRB cells (Table I). Under $\mathrm{Ca}^{2+}$ free condition, $\left[{ }^{3} \mathrm{H}\right]$ taurine uptake and efflux were significantly reduced and enhanced, respectively. In addition, $\left[{ }^{3} \mathrm{H}\right]$ taurine efflux was inhibited in the presence of $2.8 \mathrm{mM}$ (2-fold) $\mathrm{Ca}^{2+}$. Also, calcium channel blockers such as verapamil, nifedipine and nickel chloride inhibited $\left[{ }^{3} \mathrm{H}\right]$ taurine uptake in TR-iBRB cells (Fig. 1).

\section{Effect of oxidative stress on the $\left[^{3} \mathrm{H}\right]$ taurine uptake and efflux in TR-iBRB cells}

We investigated the change of $\left[{ }^{3} \mathrm{H}\right]$ taurine uptake in TR-iBRB cells under oxidative stress conditions. To induce oxidative stress conditions, TR-iBRB cells were exposed to TNF- $\alpha(20 \mathrm{ng} / \mathrm{ml})$, LPS $(10 \mathrm{ng} / \mathrm{ml})$, DEM $(100 \mu \mathrm{M})$, glutamate $(100 \mu \mathrm{M})$ and $\mathrm{SIN}-1(1 \mathrm{mM})$ for $3,6,9,12$, and $24 \mathrm{~h}$. As shown in Fig. 2, $\left[{ }^{3} \mathrm{H}\right]$ taurine uptake was increased continuously up to $24 \mathrm{~h}$ by TNF- $\alpha$, except that the cells were pretreated with TNF- $\alpha$ for $6 \mathrm{~h}$. On the other hand, pre-treatment with LPS and DEM up to $6 \mathrm{~h}$ and $3 \mathrm{~h}$, respectively, resulted in a significant increase in $\left[{ }^{3} \mathrm{H}\right]$ taurine uptake and it fell continuously down, but was still higher than control. When the cells were pretreated with DEM, $\left[{ }^{3} \mathrm{H}\right]$ taurine uptake was increased up to $3 \mathrm{~h}$ and then decreased gradually (Fig. 2). To investigate the effect of $\mathrm{NO}$ on taurine uptake, TR-iBRB cells were pre-treated for $24 \mathrm{~h}$ with $\mathrm{SIN}-1$, which is known to NO donor. [ $\left.{ }^{3} \mathrm{H}\right]$ Taurine uptake was decreased continuously up to $24 \mathrm{~h}$ by pre-treatment of SIN-1 (Fig. 2).

The effect of TNF- $\alpha$, LPS and DEM pre-treatment on the $\left[{ }^{3} \mathrm{H}\right]$ taurine efflux was also examined in TR-iBRB cells. $\left[{ }^{3} \mathrm{H}\right]$ Taurine efflux was inhibited by pre-treatment of these oxidative inducing agents for $24 \mathrm{~h}$ (Fig. 3). Then, the cells were pre-treated with TNF- $\alpha$, LPS and DEM for $24 \mathrm{~h}, 6 \mathrm{~h}$

Table I. Effect of various ions on $\left[{ }^{3} \mathrm{H}\right]$ taurine transport in TR-iBRB cells

\begin{tabular}{lcc}
\hline Conditions & $\begin{array}{c}\text { Uptake of }\left[{ }^{3} \mathrm{H}\right] \text { taurine } \\
\text { (\% of control) }\end{array}$ & $\begin{array}{c}\text { Intracellular amount of } \\
{\left[{ }^{3} \mathrm{H}\right] \text { taurine remained }} \\
\text { (\% of control) }\end{array}$ \\
\hline Control & $100 \pm 4$ & $100 \pm 4$ \\
$\mathrm{Na}^{+}$free & & $108 \pm 1^{* *}$ \\
$\mathrm{Cl}^{-}$free & $78.5 \pm 7.1^{*}$ & $111 \pm 3^{*}$ \\
$\mathrm{Ca}^{2+}$ free & $102 \pm 3$ & $85.3 \pm 0.7^{*}$ \\
2 fold $\mathrm{Ca}^{2+}$ & $134 \pm 2^{* *}$ \\
\hline
\end{tabular}

$\left[{ }^{3} \mathrm{H}\right]$ Taurine uptake and efflux study were performed under $\mathrm{Na}^{+}$, $\mathrm{Cl}^{-}, \mathrm{Ca}^{2+}$ free or 2 fold $\mathrm{Ca}^{2+}$ conditions. $\mathrm{Na}^{+}, \mathrm{Cl}^{-}$and $\mathrm{Ca}^{2+}$ were replaced with choline, gluconate and $\mathrm{Mg}^{2+}$, respectively. Each value represents the mean \pm SEM $(n=3-8) .{ }^{*} p<0.05,{ }^{* *} p<0.01$, significantly different from control.

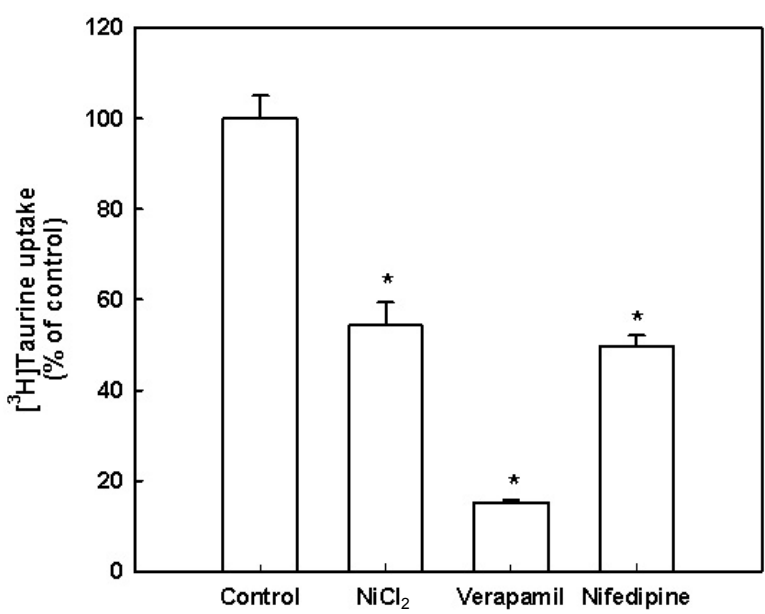

Fig. 1. Effect of calcium channel blockers on $\left[{ }^{3} \mathrm{H}\right]$ taurine uptake in TR-iBRB cells. The cells were incubated for $5 \mathrm{~min}$ at $37^{\circ} \mathrm{C}$ with ECF buffer at $1 \mathrm{mM} \mathrm{NiCl}_{2}, 0.3 \mathrm{mM}$ verapamil, $2 \mathrm{mM}$ nifedipine and nimodipine containing $\left[{ }^{3} \mathrm{H}\right]$ taurine $(28 \mathrm{nM})$. Each value represents the mean $\pm \operatorname{SEM}(\mathrm{n}=4) .{ }^{*} p<0.05$, significantly different from control.

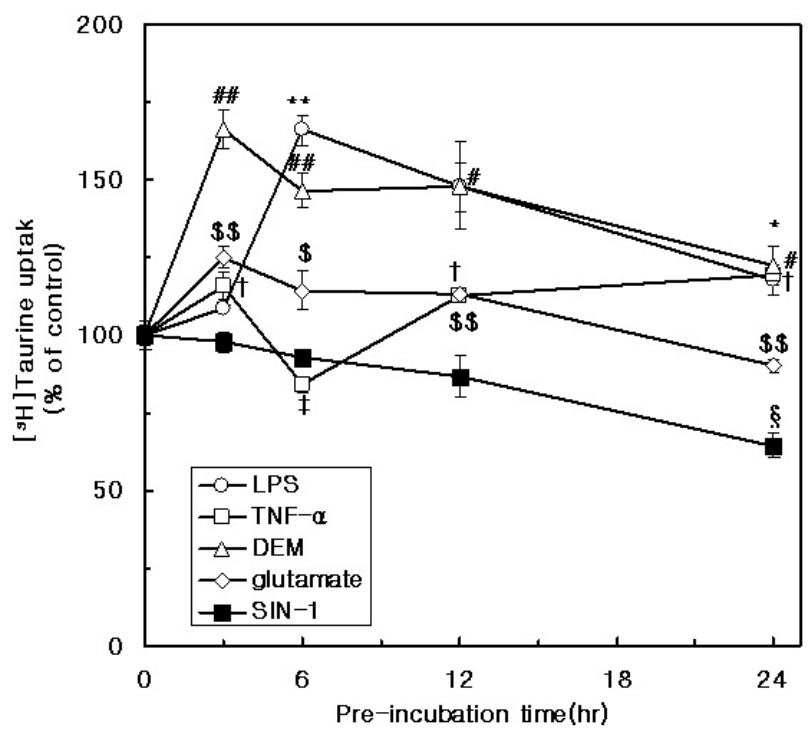

Fig. 2. Time-course of the effect by oxidative stress inducing agents on $\left[{ }^{3} \mathrm{H}\right]$ taurine uptake in TR-iBRB cells. $10 \mathrm{ng} / \mathrm{ml} \mathrm{LPS}, 20$ $\mathrm{ng} / \mathrm{ml}$ TNF- $\alpha, 100 \mu \mathrm{M}$ DEM, $100 \mu \mathrm{M}$ glutamate and $1 \mathrm{mM}$ SIN-1 were pre-incubated for the time period in the figure. The cells were incubated for $5 \mathrm{~min}$ at $37^{\circ} \mathrm{C}$ with ECF buffer containing $\left.{ }^{3} \mathrm{H}\right]$ taurine $(28 \mathrm{nM})$. Each point represents the mean \pm SEM (n=3-4). ${ }^{*} p<0.05,{ }^{* *} p<0.001$, significantly different from time 0 . ${ }^{\dagger} p<0.05,{ }^{\ddagger} p<0.01$, significantly different from time $0 .{ }^{\#} p<$ $0.05,{ }^{\#} p<0.001$, significantly different from time $0 .{ }^{\$} p<0.05$, ${ }^{\$} p<0.01$, significantly different from time $0 .{ }^{\S} p<0.05$, significantly different from time 0 . 


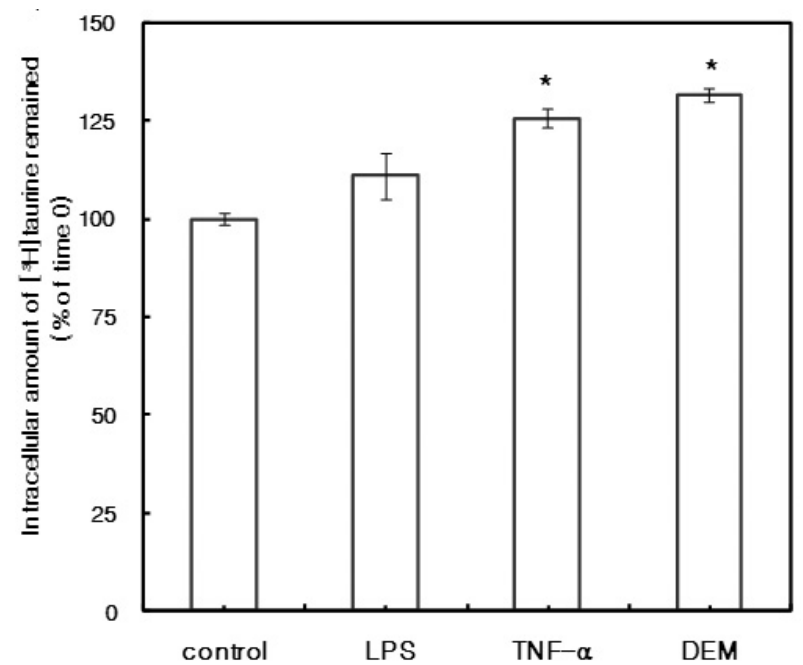

Fig. 3. Effect of oxidative stress inducing agents on the $\left[{ }^{3} \mathrm{H}\right]$ taurine efflux in TR-iBRB cells. TR-iBRB cells were pre-treated with LPS (10 ng/ml), TNF- $\alpha(20 \mathrm{ng} / \mathrm{ml})$ or DEM (100 $\mu \mathrm{M})$ for $24 \mathrm{~h}$. The cells were first incubated for $60 \mathrm{~min}$ at $37^{\circ} \mathrm{C}$ with ECF buffer containing $\left[{ }^{3} \mathrm{H}\right]$ taurine $(28 \mathrm{nM})$. Then, the media were replaced with the $1 \mathrm{~mL}$ ECF and cells were further incubated at $37^{\circ} \mathrm{C}$ for $30 \mathrm{~min}$. $\left[^{3} \mathrm{H}\right]$ Taurine amount remained the cells was measured. Each value represents the mean \pm SEM $(n=3) .{ }^{*} p<0.001$, significantly different from control.

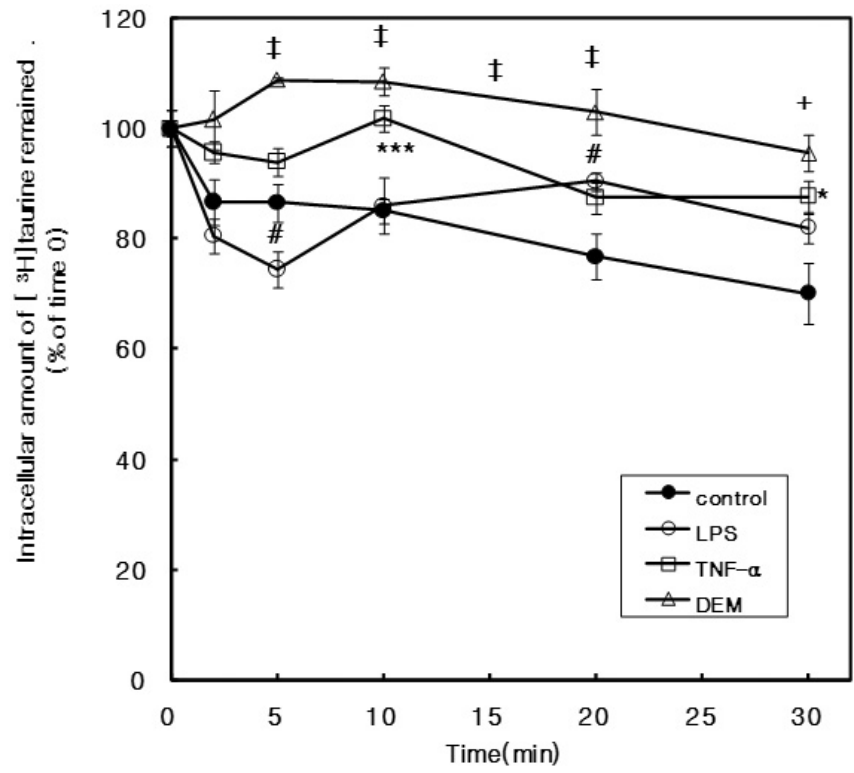

Fig. 4. Time-course of the effects by oxidative stress inducing agents on $\left[{ }^{3} \mathrm{H}\right]$ taurine efflux from TR-iBRB cells. $10 \mathrm{ng} / \mathrm{ml} \mathrm{LPS}$, $20 \mathrm{ng} / \mathrm{ml} \mathrm{TNF}-\alpha$ and $100 \mu \mathrm{M}$ DEM were pre-treated for $6 \mathrm{~h}, 24 \mathrm{~h}$ and $3 \mathrm{~h}$, respectively. Samples were taken at the times indicated and the remaining amount of $\left[{ }^{3} \mathrm{H}\right]$ taurine in the cells was measured. Each point represents the mean \pm SEM $(n=3-4)$. ${ }^{*} p<0.05,{ }^{* *} p<0.01$, significantly different from each time point of control. ${ }^{*} p<0.05$, significantly different from each time point of control. ${ }^{\dagger} p<0.05,{ }^{\dagger} p<0.01$, significantly different from each time point of control.

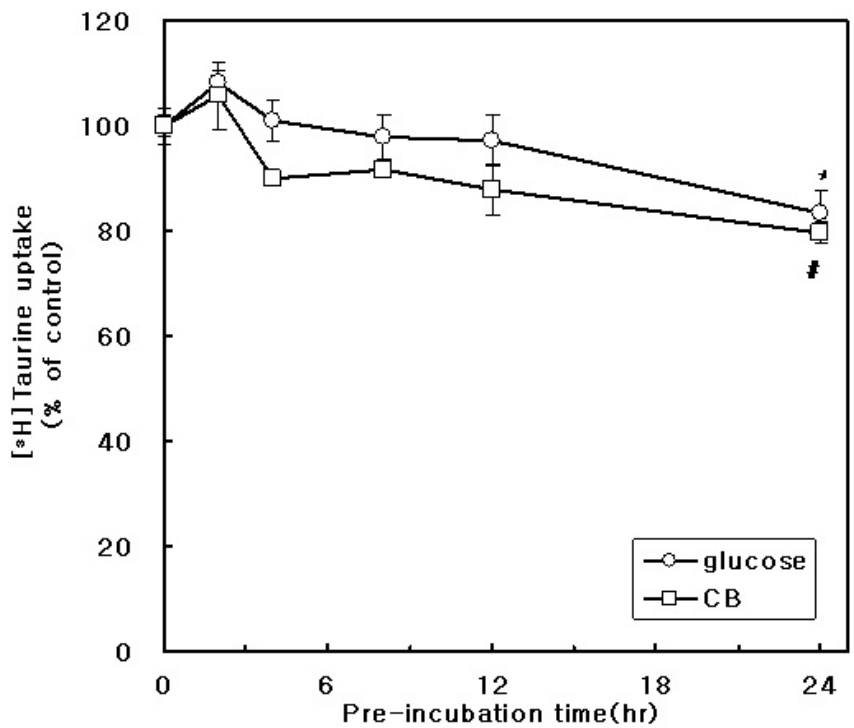

Fig. 5. Time-course of the effect of high glucose and cytochalasin $\mathrm{B}(\mathrm{CB})$ on $\left.{ }^{3} \mathrm{H}\right]$ taurine uptake by TR-iBRB cells. $25 \mathrm{mM}$ glucose or $1 \mu \mathrm{M} \mathrm{CB}$ was pre-incubated for the time period in the figure. The cells were incubated for $5 \mathrm{~min}$ at $37^{\circ} \mathrm{C}$ with ECF buffer containing $\left[{ }^{3} \mathrm{H}\right]$ taurine $(28 \mathrm{nM})$. Each point represents the mean \pm SEM $(n=3-4) .{ }^{*} p<0.05$, significantly different from time 0 . ${ }^{\#} p<0.001$, significantly different from time 0 .

and $3 \mathrm{~h}$, respectively. These pre-treatment time indicated peak time in time-course of $\left[{ }^{3} \mathrm{H}\right]$ taurine uptake obtained by pre-treatment of each oxidative stress inducing agents in TR-iBRB cells. LPS induced $\left[{ }^{3} \mathrm{H}\right]$ taurine efflux for the first 5 min significantly (Fig. 4). By TNF- $\alpha,\left[^{3} H\right]$ taurine efflux was significantly inhibited (Fig. 4). DEM showed the most biggest inhibitory effect on the $\left[{ }^{3} \mathrm{H}\right]$ taurine efflux in TR-iBRB cells (Fig. 4).

\section{Effect of hyperglycemic condition on the $\left[{ }^{3} \mathrm{H}\right]$ taurine uptake in TR-iBRB cells}

To investigate the effect of excess glucose on taurine transport at the inner BRB, $\left[{ }^{3} \mathrm{H}\right]$ taurine uptake activity was examined in TR-iBRB cells under $25 \mathrm{mM}$ glucose and $1 \mu \mathrm{M}$ $C B$ pre-treatment conditions. By exposing TR-iBRB cells to hyperglycemic conditions for $24 \mathrm{~h},\left[{ }^{3} \mathrm{H}\right]$ taurine uptake was decreased continuously (Fig. 5).

\section{DISCUSSION}

The present study demonstrated that taurine transport is regulated by extracellular $\mathrm{Ca}^{2+}$ concentration, several oxidative stresses and hyperglycemia in TR-iBRB cells, an in vitro model of the iBRB.

The presence of taurine transport at the iBRB is suggested by the fact that $\left[{ }^{3} \mathrm{H}\right]$ taurine uptake occurs in rat and 
TR-iBRB cells (Tomi et al., 2006). TauT is known to be $\mathrm{Na}^{+}$ and $\mathrm{Cl}^{-}$-dependent transporter and prefer $\beta$-amino acid like taurine and $\beta$-alanine (Smith et al., 1992). The uptake of $\left[{ }^{3} \mathrm{H}\right]$ taurine by TR-iBRB cells took place in a time, $\mathrm{Na}^{+}$ and $\mathrm{Cl}^{-}$-dependent manner (Tomi et al., 2006). Also, it is reported that there is the efflux pump for taurine at the blood-brain barrier to reduce taurine concentration in the brain interstitial fluid (Lee and Kang, 2004). In our results, $\left[{ }^{3} \mathrm{H}\right]$ taurine efflux was also observed in a time, $\mathrm{Na}^{+}$and $\mathrm{Cl}^{-}$ dependent manner in TR-iBRB cells (Table I).

The effects of extracellular $\mathrm{Ca}^{2+}$ concentration and $\mathrm{Ca}^{2+}$ channel blockers on the taurine transport in TR-iBRB cells were demonstrated. $\left[^{3} \mathrm{H}\right]$ Taurine uptake and efflux were decreased and enhanced significantly under extracellular calcium depletion (Table I and Fig.1). It is consistent with our previous study in osteocytes cell line (Kang and Kim, 2008). Also, it was reported that $\mathrm{Ca}^{2+}$ free medium enhanced the taurine efflux from the rat striatum in vivo (Molchanova et al., 2005). These results indicated that the decrease of taurine uptake under calcium depletion may be related with the increase of taurine efflux from retina.

Taurine is physiologically important as antioxidants, osmolytes, and calcium modulators. Intracellular taurine is accumulated via two mechanisms, transport from extracellular space via TauT and biosynthesis within the cell. However, regulation of taurine transport by several stresses at iBRB is still unknown. In the present investigation, TNF- $\alpha$, which is a proinflammatory cytokine induced by cell damage, LPS, which is a bacterial endotoxin, DEM, which is a compound inducing oxidative stress, and glutamate, which is an excitatory neurotransmitter were used oxidative stress inducing agents to elucidate whether the taurine transport at iBRB is regulated by oxidative stresses. In our previous report, pre-treatment of TNF- $\alpha$ in TR-BBB cell line, which is an in vitro blood-brain barrier model, increases taurine uptake by inducing the expression of TauT (Kang et al., 2002). In TR-iBRB cells, $\left[{ }^{3} \mathrm{H}\right]$ taurine uptake was also increased by TNF- $\alpha$ pre-treatment (Fig. 2). The TNF-a is known to induce nuclear factor-kB (NF-kB) by nuclear translocation, and the NF-kB binding site is found in the TauT promoter region (Han et al., 2000). Therefore, it suggested that NF-kB activated by TNF- $\alpha$ could be associated in TauT up-regulation. In addition, LPS and DEM were enhanced $\left[{ }^{3} \mathrm{H}\right]$ taurine uptake in TR-iBRB cells (Fig. 2) It is known that LPS stimulates production of many kinds of cytokines such as TNF- $\alpha$. Therefore, it may be possible that $\left[{ }^{3} \mathrm{H}\right]$ taurine uptake was increased by TNF- $\alpha$ stimulated by LPS. In contrast, LPS decreased taurine uptake significantly in macrophage cell line RAW 264.7 cell by the action of nitric oxide (NO) in- duced by LPS (Kim et al., 2003). LPS induced cell damages via diverse pathway, therefore, the mechanism study of changes of taurine uptake by LPS is needed to be further elucidated. DEM induced oxidative stress through the depletion of intracellular glutathione (GSH) and up-regulated the cystine uptake in the organ (Bannai, 1984; Hosoya et al., 2001). Taurine is also sulfur-containing amino acid like cystine, therefore, it seems that DEM may induce an increase of taurine uptake in TR-iBRB cells. In addition, our results showed that $\left[{ }^{3} \mathrm{H}\right]$ taurine efflux was inhibited by those oxidative stress inducing agents (Fig. 3 , 4). These results suggested that decrease of taurine efflux under oxidative stress conditions may be a possible mechanism for increase of retinal taurine level. In addition, the decreased taurine uptake activity was observed after pre-incubation with the NO donor, SIN-1 (Fig. 2). It was reported that NO levels are increased in diabetic retinopathy by increase of nitric oxide synthase (NOS) activity (Goldstein et al., 1996; Bridges et al., 2001). The previous report showed that taurine transport is regulated by NO and the effect on taurine transporter activity by SIN-1 was not immediate (Bridges et al., 2001). Lyall et al. (1996) demonstrated that ONOO-, which can be released from SIN-1, interacted with tyrosine residue of TauT. Also, the other reports showed that formation of nitrotyrosine was detected highly in NO donor treatment (Kulanthaivel et al., 1989; Myatt et al., 1996). These alterations of TauT induced reduction of taurine transport activity.

In diabetic state, elevated glucose level will obviously disturb cellular osmoregulation. Such disturbance in osmoregulation could result in cellular dysfunctions (McManus et al., 1995). Taurine is known to act as an organic osmolyte. The changes in taurine transporter activities have been reported in STZ-induced diabetic rats, human retinal pigment epithelial cells by high glucose and in diabetic neuropathy models (Stevens et al., 1999). Our results revealed suppressed $\left[{ }^{3} \mathrm{H}\right]$ taurine uptake in TR-iBRB cells under hyperglycemic condition (Fig. 5). Through the other study, PKC inhibitor, chelerythrine, completely eliminated the changes of taurine uptake and release and the depletion of intracellular tauirine induced by high glucose treatment (Shi et al., 2003). Presumably, high glucose stimulates the PKC activity and inhibits the transcription of TauT through the PKC phosphorylation of its transcription factors. PKC may also disturb taurine metabolism through phosphorylation of other protein, such as signal transduction proteins or even TauT itself (Shi et al., 2003).

In conclusion, taurine transport in TR-iBRB cells can be regulated by several disease conditions, which may be one of mechanisms responsible for the neuroprotection in 
response to retinal cell damage.

\section{ACKNOWLEDGMENTS}

The authors wish to thank Dr. T. Terasaki for providing TR-iBRB cell lines with kindness. This research was supported by the Sookmyung Women's University Research Grants 2009.

\section{REFERENCES}

Bannai, S. (1984). Induction of cystine and glutamate transport activity in human fibroblast by diethyl maleate and other electrophilic agents. J. Biol. Chem. 289, 2435-2440.

Bridges, C. C., Ola, M. S., Prasad, P. D., El-sherbeny, A., Ganapathy, V. and Smith, S.B. (2001). Regulation of taurine transporter expression by NO in cultured human retinal pigment epithelial cells. Am. J. Physiol. Cell Physiol. 281, 1825-1836.

Cunha-Vaz, J. G. (1976). The blood-retinal barriers. Doc. Ophthalmol. 41, 287-327.

Goldstein, I. M., Ostwald, P. and Roth, S. (1996). Nitric oxide: a review of its role in retinal function and disease. Vision Res. 36, 2979-2994.

Han, X., Budreau, A. M. and Chesney, R. W. (2000). Cloning and characterization of the promoter region of the rat taurine transporter (TauT) gene. Adv. Exp. Med. Biol. 483, 97-108.

Hayes, K. C., Carey, R. E. and Schmidt, S. Y. (1975). Retinal degeneration associated with taurine deficiency in the cat. Science. 188, 949-951.

Heller-Stilb, B., Van Roeyen, C., Rascher, K., Hartwig, H.G., Huth, A., Seeliger, M. W., Warskulat, U. and Haeussinger, D. (2002). Disruption of the taurine transporter gene (taut) leads to retinal degeneration in mice. FASEB J. 16, 231-233.

Hosoya, K., Saeki, S. and Terasaki, T. (2001). Activation of carrier-mediated transport of L-cystine at the blood-brain and blood-retinal barrier in vivo. Microvasc. Res. 62, 136-142.

Hosoya, K., Tomi, M., Ohtsuki, S., Takanaga, H., Ueda, M., Yanai, N., Obinata, M. and Terasaki, T. (2001). Conditionally immortalized retinal capillary endothelial cell lines (TR-iBRB) expressing differentiated endothelial cell functions derived from a transgenic rat. Exp. Eye Res. 72, 163-172.

Kang, Y. S. and Kim, S. J. (2008). The change of taurine transport in osteocytes by oxidative stress, hypertonicity and calcium channel blockers. Biomol. Ther. 16, 219-225.

Kang, Y. S., Ohtsuki, S., Takanaga, H., Tomi, M., Hosoya K. and Terasaki, T. (2002). Regulation of taurine trnasport at the blood-brain barrier by tumor necrosis factor-a, taurine and hypertonicity. J. Neurochem. 83, 1188-1195.

Kim, H. W., Kim, J. H., An, H. S., Park, K. K., Kim, B. K. and Park T. (2003). Myo-inositol restores the inflammationinduced down-regulation of taurine transport by the murine macrophage cell line, RAW 264.7. Life Sci. 73, 2477-2489.

Kulanthaivel, P., Leibach, F. H., Mahesh, V. B. and Ganapathy, $V$ (1989). Tyrosine residues are essential for the activity of the human placental taurine transpoter. Biochem. Biophys.
Acta. 985, 139-146.

Lee, N. Y. and Kang, Y. S. (2004). The brain-to-blood efflux transport of taurine and changes in the blood-brain barrier transport system by tumor necrosis factor-alpha. Brain Res. 1023, 141-147.

Lima, L. (1999). Taurine and its trophic effects in the retina. Neurochem. Res. 24, 1333-1338.

Lyall, F., Freer, I., Young, A. and Myatt, L. (1996). Nitric oxide concentrations are increased in the fetal-placental circulation in intrauterine growth restriction. Placenta. 17, 165-168.

McManus, M. L., Churchwell, K. B. and Strange, K. (1995). Regulation of cell volume in health and disease. N. Engl. J. Med. 333, 1260-1266.

Molchanova, S. M., Oja, S. S. and Saransaari, P. (2005). Mechanism of enhanced taurine release under $\mathrm{Ca}^{2+}$ depletion. Neurochem. Int. 47, 343-349.

Myatt, L. Rosenfield, R. B., Eis, A. L., Brockman, D. E., Greer, I. and Lyall, F. (1996). Nitrotyrosine residues in placenta. Evidence of peroxynitrite formation and action. Hypertension. 28, 488-493.

Obrosova, I. G., Minchenko, A. G., Marinescu, V., Fathallah, L. Kennedy, A., Stockert, C. M., Frank, R. N. and Stevens, M.J. (2001). Antioxidants attenuate early up regulation of retinal vascular endothelial growth factor in streptozotocin-diabeitc rats. Diabetologia. 44, 1102-1110.

Pasantes-Morales, H., Klethi, J., Ledig, M. and Mandel, P. (1972). Free amino acids of chicken and rat retina. Brain Res. 41, 494-497.

Shi, Y. R., Gao, L., Wang, S. H., Bu, D. F., Zhang, B. H., Jiang, H. F., Zheng, Y. and Tang, C. H. (2003). Inhibition of taurine transport by high concentration of glucose in cultured rat cardiomyocytes. Metabolism, 52, 827-833.

Smith, K. E., Borden, L. A. and Wang, C. R. (1992). Cloning and expression of a high affinity taurine transporter from rat brain. Mol. Pharmacol. 42, 563-569.

Stevens, M. J., Hosaka, Y., Masterson, J. A., Jones, S. M., Thomas, T. P. and Larkin, D. D. (1999). Down regulation of the human taurine transporter by glucose in cultured retinal pigment epithelial cells. Am. J. Physiol. 277, 760-771.

Stewart, P. A. and Tuor, U. I. (1994). Blood-eye barriers in the rat: correlation of ultrastructure with function. J. Comp. Neurol. 340, 566-576.

Terasaki, T. and Hosoya, K. (2001). Conditionally immortalized cell lines as a new in vitro model for the study of barrier functions. Biol. Pharm. Bull. 24, 111-118.

Tomi, M., Terayama, T., Isobe, T., Egami, F., Morito, A., Kurachi, M., Ohtsuki, S., Kang, Y. S., Terasaki, T. and Hosoya, K. (2007). Function and regulation of taurine transport at the inner blood-retinal barrier. Microvascular Res. 73, 100-106.

Tornquist, P. and Alm, A. (1986). Carrier-mediated transport of amino acids through the blood-retinal barrier and the blood-brain barriers. Graefes Arch. Clin. Exp. Ophthalmol. 224, 21-25.

Vinton, N. E., Heckenlively, J. R., Laidlaw, S. A., Martin, D. A., Foxman, S. R., Ament, M. E. and Kopple, J. D. (1990). Visual function in patients undergoing long-term total parental nutrition. Am. J. Nutr. 52, 895-902. 